\title{
THE USE OF GIS TECHNIQUES FOR OBTAINING POTENTIALLY FLOODABLE SURFACES IN THE JIJIA FLOODPLAIN
}

DOI: http://dx.doi.org/10.18509/GBP.2018.52

UDC: $627.5(498)$

\author{
Elena Hutanu ${ }^{1}$ \\ Alin Mihu-Pintilie ${ }^{2}$ \\ Andrei Urzica ${ }^{1}$ \\ Liviu Marian Albu ${ }^{1}$ \\ Vasile Bogdan Ghindaoanu ${ }^{1}$ \\ ${ }^{1}$ Alexandru Ioan Cuza University of Iasi, Faculty of Geography and Geology, Department of \\ Geography, Bd. Carol I 20A, 700505, Iasi, Romania \\ ${ }^{2}$ Alexandru Ioan Cuza University of Iasi, Interdisciplinary Research Department - Field \\ Science, 54 Lascar Catargi St., 700107, Iasi, Romania
}

\begin{abstract}
The density of the hydrographical network in Romania is high; hence, many settlements are situated in the major floodplain, which is often subjected to floods. The elaboration of hydrological risk maps for the major hydrographical arteries is extremely useful for the development plans of human settlements within plateaus and plains. The Jijia River is the main tributary within the northern sector of the Prut River. It dredges the Moldavian Plain from the NW towards the SE. The modelling of floods in the floodplain of the Jijia River involved three stages. In the first stage, the data necessary for simulating floods were collected (i.e. maximum flows from the hydrometric stations and the LIDAR data). In the second stage, the data obtained were processed (theoretical flows with assurances of $0.1 \%, 1 \%, 3 \%$ and $5 \%$ were calculated using the Pearson III formula and the LIDAR data were processed). In the third stage, the floodable stripes were obtained using the software programs Arc-GIS, HEC-GeoRAS and HEC-RAS. Finally, maps with potential floodable areas were generated. The floodable surface on the Jijia River is $119.078 \mathrm{~km}^{2}$ for the assurance of $0.1 \%, 102.06 \mathrm{~km}^{2}$ for the assurance of $1 \%, 84.99 \mathrm{~km}^{2}$ for the assurance of $3 \%$ and $71.45 \mathrm{~km}^{2}$ for the assurance of $5 \%$. Along with the potentially floodable surface, the level of flooding was obtained: it reached a peak value of $6.83 \mathrm{~m}$ in case of the assurance of $0.1 \%$. Using the existing data, an analysis was conducted regarding the potential risks in case of major floods. The purpose of the study is to prevent floods and to mitigate their effects on the human settlements within the floodplain of the Jijia River.
\end{abstract}

Keywords: human settlements, flood mitigation, historic floods, effects

\section{INTRODUCTION}

Floods are the most devastating phenomena that cause major changes in the topographic area over time, affecting socially and economically human communities. Overlapping abundant precipitation with the sudden melting of snow is the main cause of floods in the temperate zone. In Romania, this phenomenon manifests itself most frequently at the beginning of the spring [1-7]. 
Regarding the floods that occur in the NE of Romania, there are several studies in national [8-13] and international literature [14-17] which identified and described the extreme phenomena associated with the maximum leakage and the devastating effect of their manifestation. In 2013, the first floodplains were made by The Prut-Barlad River Basin Administration, using LiDAR and the MIKE software.

The present paper aims at carrying out a flood simulation with the assurance of $0.1 \%, 1 \%$, $3 \%$ and 5\% using the HEC-RAS methodology. Thus, the hydrological risk map for the Jijia River basin is further developed, in addition to the data of the Prut-Barlad River Basin Administration.

\section{STUDY AREA}

The Jijia hydrographic basin is located in the north-eastern part of Romania, being part of the Moldavian Plain. From the hydrographic point of view, the Jijia basin area is part of the Prut River basin, the Jijia River being a tributary of its right. From the administrative and territorial point of view, the study area corresponds to the counties of Botosani and Iasi (Fig.1).

The geological deposits specific to the Jijia River basin belong to the Upper Holocene and the Upper Pleistocene. From a climatic point of view, in the Jijia River basin, an average annual temperature of 9 to $9.5^{\circ} \mathrm{C}$ is recorded and the annual rainfall is relatively small compared to the country average, with values ranging from 550 to $600 \mathrm{~mm}$ per year . The climatic characteristics, vegetation and rock type of the Jijia River meadow have facilitated the development of Aluviosol soils, predominantly eutrium Aluviosol. Also in the meadow area there are Solonet soil areas.

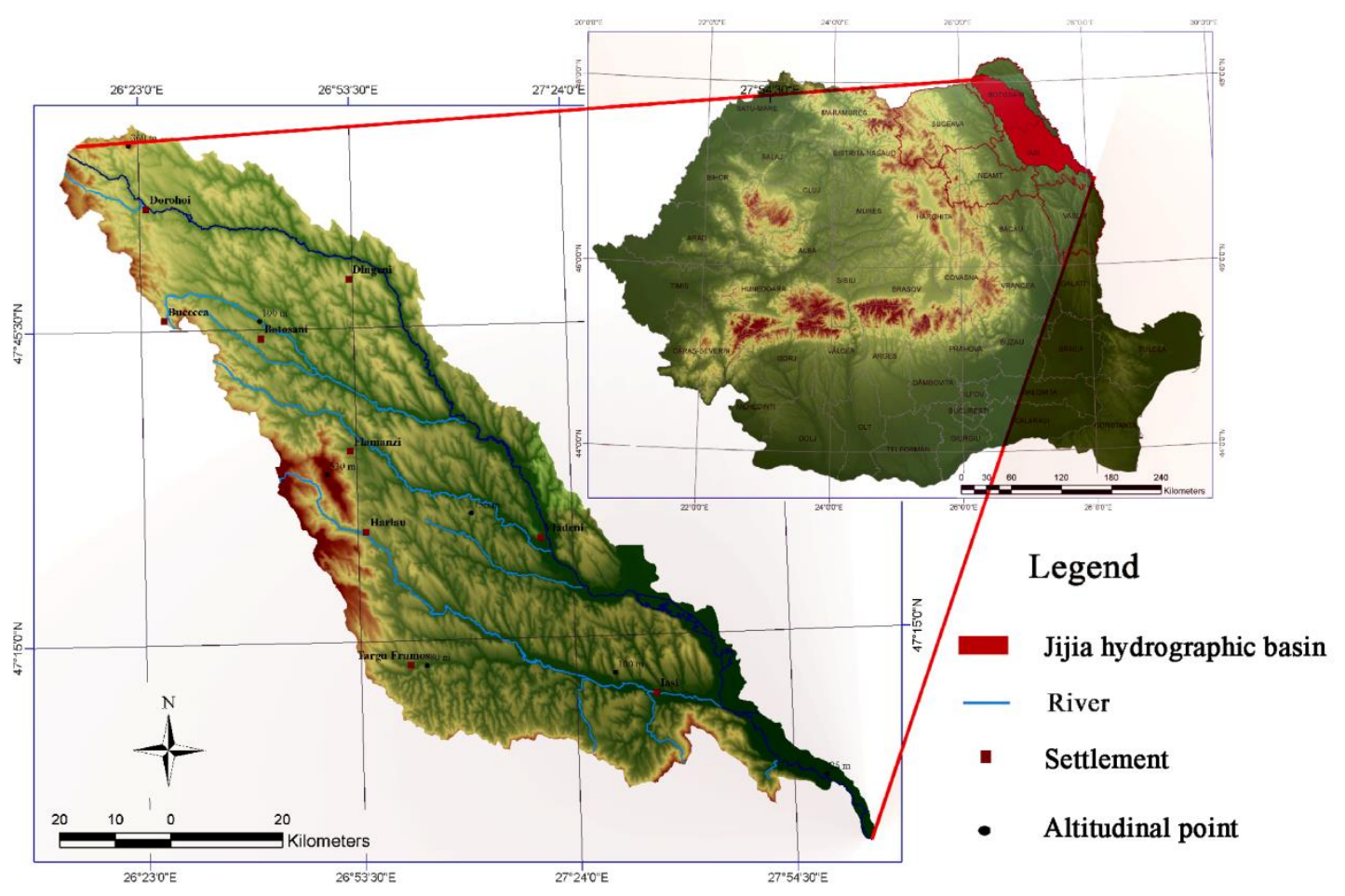

Figure 1. The location of the Jijia River basin on the territory of Romania 


\section{METODOLOGY}

To carry out the present study, it was necessary from the beginning to digitize the relief elements that formed the basis for flood modeling in order to obtain floodable surfaces. The spatial database was extracted from a Digital Trainee Model (DTM) obtained by LiDAR technology (DTM resolution of $0.5 \mathrm{~m}, 1: 5,000$ ) and bounded by aerial images (orthophotomaps with a resolution of $0.5 \mathrm{~m}, 1: 5,000$ ). Vector digitization and simulation of flood strips were performed using ArcGIS software and HEC-RAS and HEC-GeoRAS extension [18-20]. To simulate flood strips, it was necessary to generate the following vector strata: the Jijia River valley, which coincides with the drainage channel, the banks of the minor bed, the major bed, the land use mode, as well as cross-sections with an equidistance between $20 \mathrm{~m}$ in the case sinuous sectors, and up to $300 \mathrm{~m}$ in the case of low sinusoidal sectors. For flood HEC-RAS simulation, based on the LiDAR-type elevation raster, a tin file for the Jijia River meadow was generated. The flood simulation was performed for four levels of insurance, these being: $0.1 \%, 1 \%, 3 \%$ and $5 \%$. For the calculation of the flood probabilities, the flow rates and daily levels from four hydrometric stations on the Jijia River from 1969 to 2015 were obtained from the PrutBarlad River Basin Administration.

Given that the data is only available for 46 years, and for calculating the probability of occurrence of a hydrological phenomenon over a period of 100-1,000 years, data is required over the 1,000 year period, it has been calculated theoretical assurance with the Pearson III formula (Eq.1):

$$
\text { Eq.1: } \mathrm{Q}_{\mathrm{p} \%}=\mathrm{Q}_{\mathrm{med}} *\left(1+\mathrm{Cv}^{*} \varphi_{\mathrm{p}} \%\right)
$$

where: $Q_{p}$ - the insurance rate flow; $Q_{m e d}$ - average rate flow; $C_{v}-$ coefficient of variation; $\varphi_{p} \%$ ordinate of the insurance curve for $\mathrm{Cv}=1$

For the recorded data the empirical assurance was calculated using Weibull's formula (Eq.2):

$$
\text { Eq.2: } \mathrm{Pi}=\mathrm{i} /(\mathrm{n}+1)^{*} 100
$$

where: Pi $\%$ - probability of occurrence of a measured rate flow; $\mathrm{i}$ - order number of decreasing orderly rate flow; $\mathrm{n}$ - the total number of string terms

To calculate the water volume as part of the floods taken over by lakes located in the Jijia River meadow, the formula (Eq.3) was used:

$$
\text { Eq.3: } \mathrm{V}=\mathrm{S}_{1}+\mathrm{S}_{2} / 2 * \mathrm{~h}
$$

where: $\mathrm{V}$ - the volume taken over; $\mathrm{S}_{1}-$ surface of lake water; $\mathrm{S}_{2}$ - the total surface of the lake; $\mathrm{h}$ - the difference between the lake and the sum of the flood rate with the topographic surface [2126].

\section{RESULTS AND DISCUSSIONS}

To assess the hydrological risk and vulnerability of the Jijia meadow population, several floodplains were generated with theoretical assurance of 5\% (20 years), 3\% (33 years), $1 \%$ (100 years), and $0,1 \%$ (1,000 years). These simulations were designed to analyze potentially flooded areas, assess the damage they generate, and look for new solutions to mitigate them (Table 1). 
Table 1. Theoretical flows $\left(\mathrm{m}^{3} / \mathrm{s}\right)$ calculated using Pearson III formula

\begin{tabular}{cccc}
\hline \multirow{2}{*}{$\begin{array}{c}\text { Type of discharge } \\
\text { probability }\end{array}$} & \multicolumn{3}{c}{ Theoretical discharge $\mathbf{~ m}^{\mathbf{3}} / \mathbf{s}$ calculated for 3 gauge stations } \\
\cline { 2 - 4 } $\mathbf{0 . 1 \%}$ & Dorohoi & Dângeni & Todireni \\
\hline $\mathbf{1 \%}$ & 356.16 & 261.18 & 471.34 \\
$\mathbf{3 \%}$ & 211.49 & 174.71 & 286.45 \\
$\mathbf{5 \%}$ & 145.81 & 134.59 & 208.60 \\
& 115.46 & 116.26 & 171.97 \\
\hline
\end{tabular}

Flood probability of $\mathbf{5 \%}$. The total flood area generated by a 5\% assurance flow reaches a value of $71.44 \mathrm{~km}^{2}$ and is manifested along the Jijia River meadow (Fig. 2). The maximum flood level, associated with $5 \%$ probability of occurrence, reaches a value of $5.90 \mathrm{~m}$ in the narrow areas of Jijia meadow, especially in the floodplain areas between Dorohoi and Dangeni hydrometric stations. In the sinking areas of the small bed, the floodplain area widens, but the level of flood water is lower.

The minimum level reached by the flood with the probability of $5 \%$ is $0.24 \mathrm{~m}$ in the meadow areas with a larger width, but also at the ends of the flood plain. Lakes and ponds located in the major meadow of the rivers take up a volume of water, greatly attenuating the flood. Thus, Lake Iezer takes 8.87 million $\mathrm{m}^{3}$ of water, thus protecting the city of Dorohoi from major waters. Borsa and Campeni lakes take a volume of water of 1.77 million $\mathrm{m}^{3}$ and 0.41 million $\mathrm{m}^{3}$ respectively (Fig. 3).

Flood probability of $3 \%$. In the case of flood simulation obtained with $3 \%$ probability flows, the flow rates of $145.81 \mathrm{~m}^{3} / \mathrm{s}$ for the Dorohoi hydrometer station, $134.59 \mathrm{~m}^{3} / \mathrm{s}$ for Dangeni and $208.60 \mathrm{~m}^{3} / \mathrm{s}$ for Todireni were introduced in the HEC-RAS software. Thus, a floodable area of $84.98 \mathrm{~km}^{2}$ was obtained (Fig. 2). Depending on the sinking of the minor bed and the major bed topography, this area narrows in certain areas where the flood level increases to a maximum of $6.07 \mathrm{~m}$. The minimum level is recorded, as with the flood with the probability of 5\%, towards the extremities of the floodplain, as well as in downstream areas where hydro-technical embankment works have been carried out, which mitigate the flood. The minimum flood level is $0.25 \mathrm{~m}$ (Fig. 3).

Flood probability of $1 \%$. For simulation of flood with the probability of producing a 1 to 100 year frequency flow, the theoretical flows obtained with Pearson III formula were introduced into the HEC-RAS software. Thus, for the Dorohoi hydrometric station the flow rate was $211.47 \mathrm{~m}^{3} / \mathrm{s}$, for Dangeni $174.71 \mathrm{~m}^{3} / \mathrm{s}$, and for Todireni $286.45 \mathrm{~m}^{3} / \mathrm{s}$ (Table 1). The flooded area is $102.05 \mathrm{~km}^{2}$ (Fig. 2) and the maximum flood level is $6.35 \mathrm{~m}$. The minimum level is recorded, as in previous cases, at the extremities and in the areas where the Jijia River has been regularized, the value being $0.26 \mathrm{~m}$ (Fig. 3).

Flood probability of $\mathbf{0 . 1 \%}$. For simulation of the flood with a probability of $0.1 \%$, the flows $365.16 \mathrm{~m}^{3} / \mathrm{s}$ for Dorohoi station, $261.18 \mathrm{~m}^{3} / \mathrm{s}$ for Dangeni and $471.34 \mathrm{~m}^{3} / \mathrm{s}$ for Todireni were introduced. Thus, by processing the data, it was obtained a $0.1 \%$ flood band. The flooded area is $119.07 \mathrm{~km}^{2}$ (Fig. 2). The average flood level is $3.55 \mathrm{~m}$, the maximum is $6.83 \mathrm{~m}$ and the minimum is $0.28 \mathrm{~m}$ (Fig. 3).

\section{CONCLUSIONS}

The objective of this study was to estimate and model in the GIS environment potential flood plains in the Jijia River basin with 1,000 year, 100 year, 33 year and 20 year demonstration frequencies and floodplains. Following flood bands, floodplains were obtained with the following values: $119.08 \mathrm{~km}^{2}$ for the flood with a probability of $0.1 \%$, $102.06 \mathrm{~km}^{2}$ for the flood with a probability of $1 \%, 84.99 \mathrm{~km}^{2}$ for the flood with a 
probability of $3 \%$ and $71.45 \mathrm{~km}^{2}$ for flood with a probability of $5 \%$. As far as potential floods are concerned, they can reach a maximum of over $6 \mathrm{~m}$, which could lead to considerable damage. By obtaining flood strips and their levels, settlements with high flood potential can be identified and timely action can be taken to mitigate floods and reduce damage.
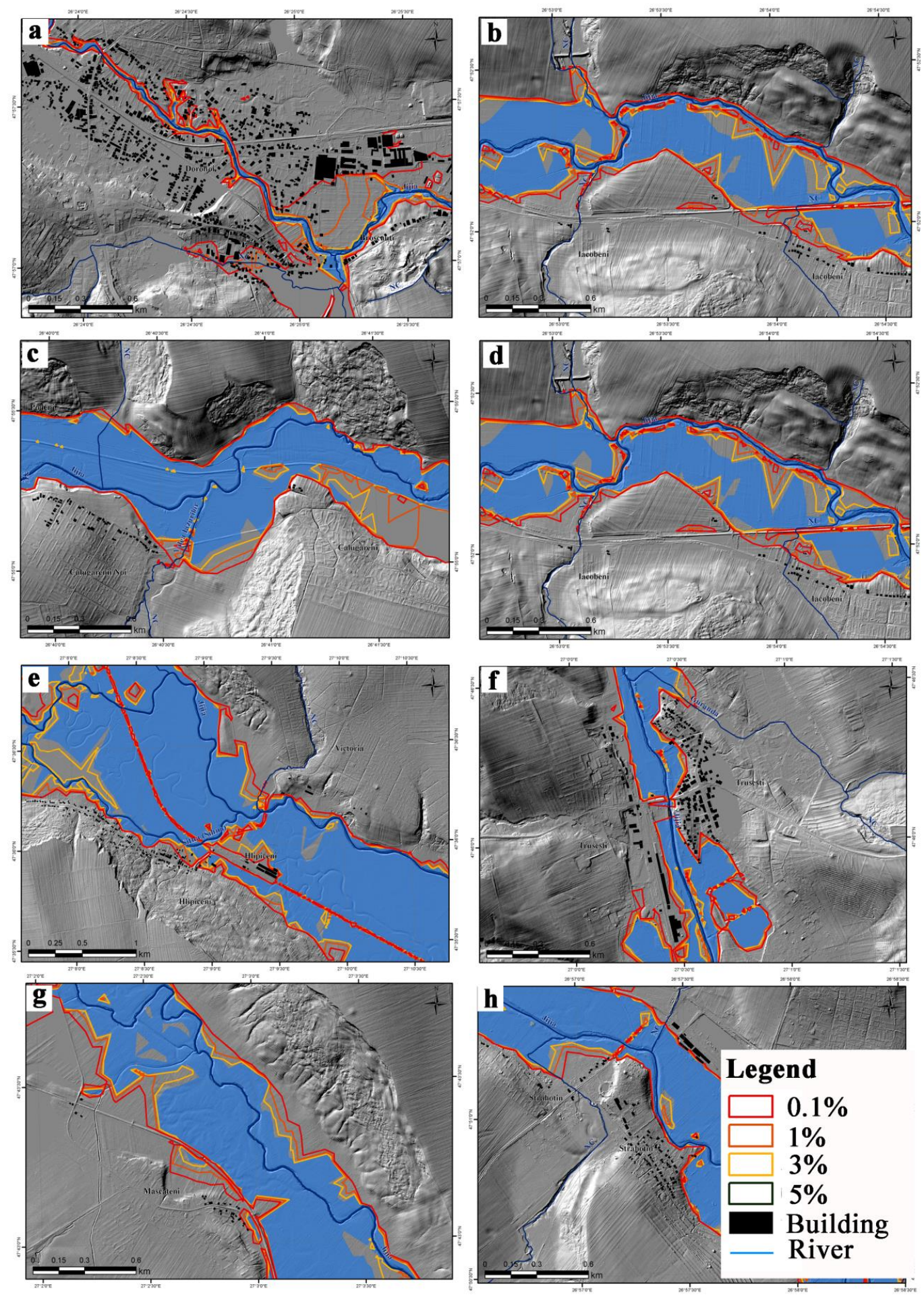

Figure 2. Cartographic representation of floodable areas with assurance of de $0.1 \%, 1 \%, 3 \%$ and $5 \%$ : a. Dorohoi locality; b. Iacobeni locality; c. Calugareni locality; d. Broscauti locality; e. Hipiceni locality; f. Trusesti locality; g. Mascateni locality; h. Strahotin and Dangeni localities. 

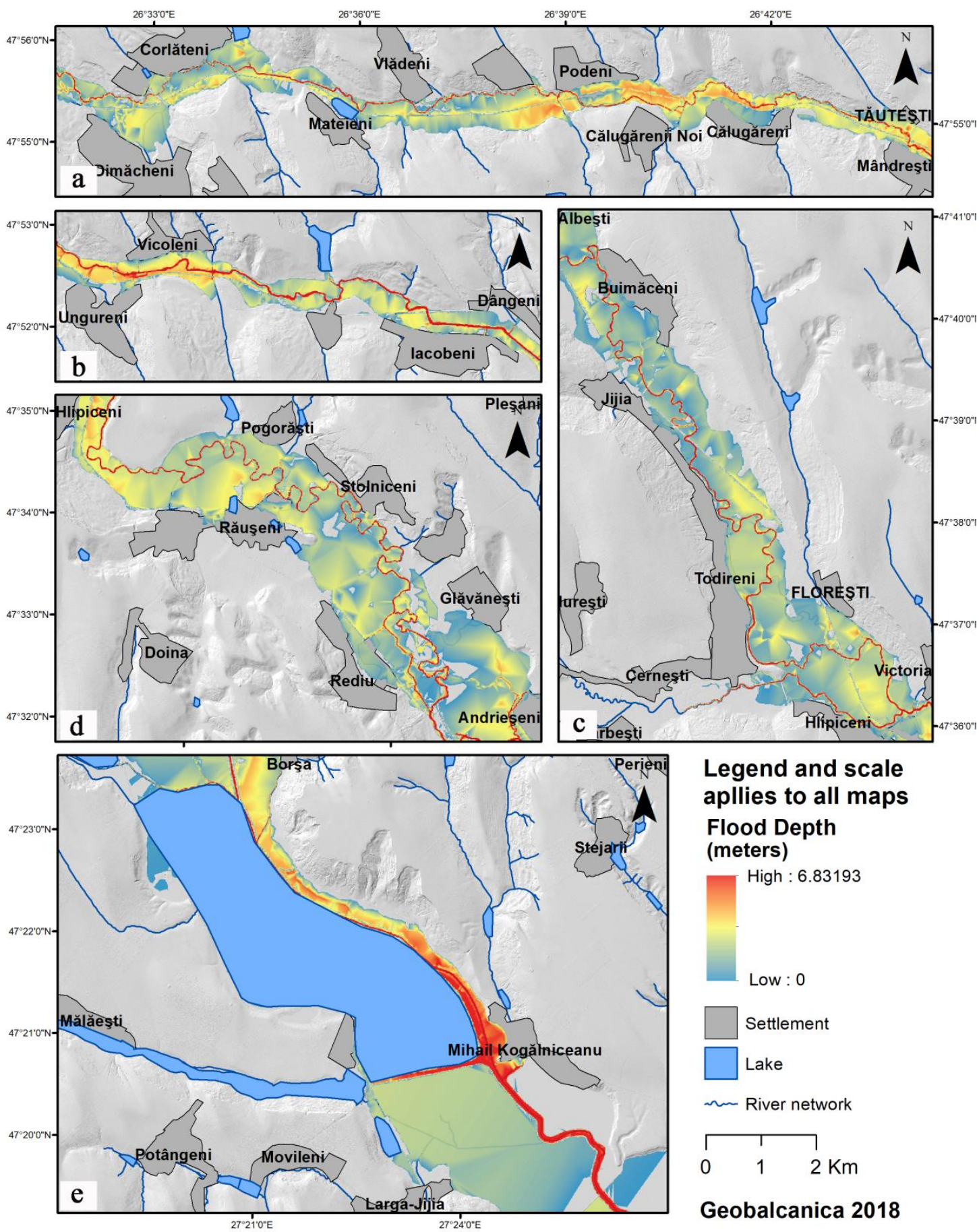

Figure 3. Cartographic representation of flood band levels with the probability of occurrence of 1 in 1,000 years: a. Higher sector; b. Ungureni - Dangeni sector; c. the Albesti - Hipiceni sector; d. the Hipiceni-Andrieseni sector; e. Lower sector 


\section{REFERENCES}

[1] Romanescu G., Stoleriu C.C. \& Romanescu A.M, Water reservoirs and the risk of accidental flood occurrence. Case study: Stanca-Costeşti reservoir and the historical floods of the Prut river in the period July-August 2008, Romania, Hydrological Processes, United States, vol. 25, pp. 2056-2070, 2011.

[2] Romanescu G., Zaharia C. \& Stoleriu C.C., Long-term changes in average annual liquid flow river Miletin (Moldavian Plain), Carpathian Journal and Earth Environmental Sciences, Romania, vol. 7, pp. 161-170, 2012.

[3] Romanescu G., Cimpianu C.I., Mihu-Pintilie A. \& Stoleriu C.C., Historic flood events in NE Romania (post-1990), Journal of Maps, United Kingdom, vol. 13, pp. 787-798, 2017.

[4] Romanescu G., Jora I. \& Stoleriu C.C., The most important high floods in Vaslui river basincauses and consequences, Carpathian Journal and Earth Environmental Sciences, Romania, vol. 6, pp. 119-132, 2011.

[5] Romanescu G. \& Nistor I., The effect of the July 2005 catastrophic inundations in the Siret River's Lower Watershed, Romania, Natural Hazards, vol. 57, no. 2, pp. 345-368, 2011.

[6] Romanescu G., Tarnovan A., Sandu I.G., Cojoc G.M., Dascalita D. \& Sandu I., The Quality of Surface Waters in the Suha Hydrographic Basin (Oriental Carpathian Mountains), Rev. Chim. (Bucharest), vol. 65, no. 10, pp. 1168-1171, 2014.

[7] Romanescu G., Hapciuc O.E., Minea I. \& Iosub M., Flood vulnerability assessment in the mountain-plateau transition zone. Case study for Marginea village (Romania), Journal of Flood Risk Management, vol. 11, no. S1, pp. S502-S513, 2018.

[8] Romanescu G. \& Stoleriu C.C., Exceptional floods in the Prut basin, Romania, in the context of heavy rains in the summer of 2010, Natural Hazards and Earth System Sciences, Germany, vol. 17, pp. 381-396, 2017.

[9] Romanescu G. \& Stoleriu C.C., An inter-basin backwater overflow (the Buhai Brook and the Ezer reservoir on the Jijia River, Romania), Hydrological Processes, United States, vol. 28, pp. 3118-3131, 2013.

[10] Romanescu G. \& Stoleriu C.C., Causes and effects of the catastrophic flooding on the Siret River (Romania) in July-August 2008, Natural Hazards, Netherlands, vol. 63, pp. 1351-1367, 2013.

[11] Romanescu G., Cotiuga V., Asandulesei A. \& Stoleriu C., Use of the 3-D scanner in mapping and monitoring the dynamic degradation of soils. Case study of the Cucuteni-Baiceni Gully on the Moldavian Plateau (Romania). Hydrology and Earth System Sciences, Germany, vol. 16, pp. 953-966, 2012.

[12] Romanescu G., Cretu M.A., Sandu I.G., Paun E. \& Sandu I., Chemism of Streams Within the Siret and Prut Drainage Basins, Water Resources and Management.Rev. Chim. (Bucharest), Romania, vol. 64, pp. 1416-1421, 2013.

[13] Romanescu G. \& Stoleriu C., Anthropogenic interventions and hydrological-risk phenomena in the fluvial-maritime delta of the Danube (Romania), Ocean\&Coastal Management, United Kingdom, vol. 102, pp. 123-130, 2014.

[14] Radevski I. \& Gorin S., Floodplain analysis for different return periods of river Vardar in Tikvesh valley (Republic of Macedonia), Carpathian Journal of Earth and Environmental Sciences, Romania, vol. 12, pp. 179-187, 2017.

[15] Tošić R., Lovrić N., Dragićević S. \& Manojlović S., Assessment of torrential flood susceptibility using GIS matrix method: case study - VRBAS river basin (B\&H), Carpathian Journal of Earth and Environmental Sciences, vol. 13, no. 2, pp. 369-382, 2018. 
[16] Ten Brinke W.B.M., Knoop J., Muilwijk H. \& Ligtvoet W., Social disruption by flooding, a European perspective, International Journal of Disaster Risk Reduction, vol. 21, pp. 312-322, 2017.

[17] Van Leeuwen B., Pravetz T., Liptay Z.A. \& Tobak Z., Physically based hydrological modelling of inland excess water, Carpathian Journal of Earth and Environmental Sciences, vol. 11, no. 2, pp. 497-510, 2016.

[18] Diaconu D.C., Andronache I., Ahammer H., Ciobotaru A.M., Zelenakova M., Dinescu R., Pozdnyakov A.V. \& Chupikova S.A., Fractal drainage model - a new approach to determinate the complexity of watershed, Acta Montanistica Slovaca, vol. 22, no. 1, pp. 12-21, 2017.

[19] Castillo C. \& Gómez J.A., A century of gully erosion research: Urgency, complexity and study approaches, Earth-Science Reviews, vol. 160, pp. 300-319, 2016.

[20] Kominkova D., Nabeikova J. \& Vitvar T., Effects of combined sewer overflows and storm water drains on metal bioavailability in small urban streams (Prague metropolitan area, Czech Republic), Journal of Soils and Sediments, vol. 16, no. 5, pp. 1569-1583, 2016.

[21] Albrecht, J., Key Concepts \& Techniques in GIS, Edition SAGE, 2007.

[22] Fasken G.B., Guide for selecting roughness coefficient "n" values for channels, Lincoln, Nebraska, 1963.

[23] Kennedy M., Introducing Geographic Information Systems with ArcGis, Third Edition, University of Kentucky, 2013.

[24] Longley P.A., Goodchild M, Maguire D., Thind D., Geographical Information Systems and Science, England, Edit. John Wiley \& Sons, 2005.

[25] Systems B., Dyhouse G., Hatchett J, Benn J, Floodplain Modeling Using HEC-RAS, Bentley Insitute Press, Exton, Pennsylvania, 2003.

[26] Xiao N., Kwan M., Goodchild M., Shekhar, S., Geographic Information Science, 7th International Conference, GIScience 2012, Columbus, OH, USA, September 2012, Edit.Springer, 1012 . 